TABLE 3

EFFECT OF PROGRAMS TO LIMIT USE OF VANCOMYCIN

\begin{tabular}{|c|c|c|c|c|c|}
\hline Program & Intervention & $\begin{array}{c}\text { No. of } \\
\text { Vancomycin } \\
\text { Orders }\end{array}$ & $\begin{array}{c}\text { Decrease } \\
\text { In Grams } \\
\text { Used }\end{array}$ & $\begin{array}{c}\text { Annualized } \\
\text { Savings } \\
\text { on Vancomycin } \\
\end{array}$ & $\begin{array}{c}\text { Decrease } \\
\text { In Incldence } \\
\text { of VRe }\end{array}$ \\
\hline This study & Infectious diseases-pharmacy team, 72 -h ASO & 675 & Yes & Yes & NR \\
\hline Morgan, $1997^{11}$ & 96-h ASO & 333 & Yes & Yes & No \\
\hline Anglim, $1997^{12}$ & Pharmacy monitoring & 54 & Yes & Yes & Yes \\
\hline Adachi, $1997^{4}$ & Order sheet & 37 & Yes & NR & No \\
\hline Burke, $1997^{5}$ & Order sheet, ASO & NR & Yes & Yes & Yes \\
\hline Belliveau, $1996^{13}$ & Infectious diseases-pharmacy team, ASOs & 386 & Yes & NR & NR \\
\hline Montecalvo, $1995^{9}$ & Infectious diseases consult & NR & Yes & Yes & NR \\
\hline Morris, $1995^{14}$ & Infectious diseases-pharmacy team & 462 & Yes & NR & No \\
\hline
\end{tabular}

Abbreviations: ASO, automatic stop order; NR, not reported; VRE, vancomycin-resistant enterococci.

a concomitant decrease in colonization or infection of patients by VRE, and three reported no change. This probably reflects the multifactorial nature of antibiotic resistance $^{6}$ and the need to control variables in addition to antibiotic use.

\section{REFERENCES}

1. Evans $\mathrm{ME}$, Kortas $\mathrm{KJ}$. Vancomycin use in a university medical center: comparison with hospital infection control practices advisory committee guidelines. Infect Control Hosp Epidemiol 1996;17:356-359.

2. Pestotnik SL, Classen DC, Evans S, Burke JP. Implementing antibiotic practice guidelines through computer-assisted decision support: clinical and financial outcomes. Ann Intern Med 1996;124:884-890.

3. Frank MO, Batteiger BE, Sorensen SJ, Hartstein AI, Carr JA, McComb 'JS, et al. Decrease in expenditures and selected nosocomial infections following implementation of an antimicrobial-prescribing improvement program. Clinical Performance and Quality Health Care 1997;5:180-188.

4. Adachi W, Bolding F, Armstrong R. Experience with vancomycin education and order sheet to limit vancomycin use. Hospital Pharmacy 1997;32:1370-1373.

5. Burke CE, Piper J, Holloway W. Order form for restricting vancomycin prescribing. Am J Health Syst Pharm 1997;54:1893-1987.

6. McGowan JE. Do intensive hospital antibiotic control programs prevent the spread of antibiotic resistance? Infect Control Hosp Epidemiol 1994;15:478-483.

7. Hospital Infection Control Practices Advisory Committee, Centers for Disease Control and Prevention. Preventing the spread of vancomycin resistance: a report from the Hospital Infection Control Practices Advisory Committee prepared by the subcommittee on prevention and control of antimicrobial-resistant microorganisms in hospitals. Infect Control Hosp Epidemiol 1995;16:105-113.

8. Centers for Disease Control and Prevention. Drug-resistant Streptococcus pneumoniae-Kentucky and Tennessee, 1993. MMWR 1994;43:23-25.

9. Montecalvo MA, Horowitz HW, Nadelman R, Nowakowski J, Andryshak $\mathrm{C}$, Colbi D, et al. Controlling IV vancomycin on an oncology unit by infectious diseases consultation. In: Program and Abstracts of the Interscience Conference on Antimicrobial Agents and Chemotherapy; September 1995; San Francisco, CA. Abstract 107.

10. Singer MV, Haft R, Barlam T, Aronson M, Shafer A, Sands KE. Vancomycin control measures at a tertiary-care hospital: impact of interventions on volume and patterns of use. Infect Control Hosp Epidemiol 1998;19:248-253.

11. Morgan AS, Brennan PJ, Fishman NO. Impact of a vancomycin restriction policy on use and cost of vancomycin and incidence of vancomycinresistant Enterococcus. Ann Pharmacother 1997;31:970-973.

12. Anglim AM, Klym B, Byers KE, Scheld WM, Farr BM. Effect of a vancomycin restriction policy on ordering practices during an outbreak of vancomycin-resistant Enterococcus faecalis. Arch Intern Med 1997;157:1132-1136.

13. Belliveau PP, Rothman $\mathrm{AL}$, Maday $\mathrm{CE}$. Limiting vancomycin use to combat vancomycin-resistant Enterococcus faecium. Am J Health Syst Pharm 1996;53:1570-1575.

14. Morris JG, Shay DK, Hebden JN, McCarter RI, Perdue BE, Jarvis W, et al. Enterococci resistant to multiple antimicrobial agents, including vancomycin. Establishment of endemicity in a university medical center. Ann Intern Med 1995;123:250-259.

\title{
Maintenance of Ice Machines
}

\section{Gina Pugliese, RN, MS Martin S. Favero, PhD}

The CDC recently published an advisory on sanitary care and maintenance of ice storage chests and icemaking machines in healthcare facilities. The advisory points out the risks and sources of contamination and includes recommendations for educa- tion of workers (hand washing, proper use of the ice scoop, and caution against handling ice with hands). Guidelines are included on the maintenance of the ice scoop and machines, including daily cleaning of scoop and ice tray with soap and water or in a dishwasher, cleaning of open ice storage chests on a preset schedule with a final rinse of $100 \mathrm{ppm}$ chlorine solution, and regularly scheduled disas- sembly and cleaning of ice-making machines. Routine microbiological sampling of ice or ice-making machines is not recommended.

FROM: Manangan LP, Anderson RL, Arduino MJ, Bond WW. Sanitary care and maintenance of ice-storage and ice-making machines in health care facilities. Am I Infect Control 1998;28:111-112. 